the evaluation of thermal efficiency, for example, a performance evaluation model was established based on energy-efficiency mechanism modeling [1], and performance evaluation model was established based on heat loss method [2]. Failure analysis was carried out on a prematurely failed tertiary super heater tube used in gasfired boiler [3]. For the operational performance boilers, the performance of a very common commercial premixed boiler setup with cylindrical premixed burners has been studied, the aim is to generate knowledge on applied premixed combustion and find the contribution of metal fiber combustion action [4]. With the investigation of denitration efficiency of transition metal oxide oxygen carriers for the gas-fired boiler flue gas, the results showed that with the reduced oxygen carriers, NO can be reduced to $\mathrm{N}_{2}$ with direct reaction and the carriers can also be converted to the oxidized oxygen carriers at the same time [5]. The study of heat transfer efficiency, emission concentrations of $\mathrm{CO}$ and $\mathrm{NO}_{x}$ of a heat exchanger by an efficiency bench test of the gas-fired boiler has been carried out, and results showed that the excess air coefficient has a significant effect on the heat efficiency, $\mathrm{CO}$ and $\mathrm{NO}_{x}$ emission concentrations of the water heater [6]. The development of visualisation and measurement of multi-burner flame in an instrumentation system is introduced, and the size, temperature and oscillation frequency of flame were quantitatively determined with the flame images obtained [7]. An improved methodology to compare a traditional natural gas combined cycle plant with a distributed energy resource combined heat and power system has been put forward [8]. With a given exhaust gas temperature, the operation regulation of coupled high-low energy flue gas waste heat recovery system was carried out to maintain the exhaust gas temperature under different flue gas flow, flue gas temperature and air temperature conditions [9].

By choosing several relevant influencing factors, an evaluation model can be established to evaluate the performance of boilers comprehensively. Principal component analysis, as a basic mathematical analysis method, is widely used in practice. In terms of energy, the analysis method is widely used in building energy. Principal component analysis was used for plugging detection and identification for final super heater tube banks with tube temperature data, which show that the method can detect and identify plugged tubes successfully, and categorical principal components analysis has been used to examine the views of people involved in ground source heat pump sector $[10,11]$. Based on principal component analysis, the model built for automatic online fault detection, diagnose and sensor reconstitution scheme, that captures the correlation among the flow meters and temperature sensors installed in the chilling systems has been presented [12]. The principal component analysis is used to select the significant modeling inputs and simplify the artificial neural network model for hourly prediction of building electricity consumption, the proposed prediction model obtained can be used for building electricity consumption online prediction [13]. Three regression variables including synthetic data sequences, outdoor specific humidity and solar radiation were selected for regression analysis, and the principal component analysis seemed to perform better than multiple regression analysis [14]. In addition, the principal component analysis method is also used in botany, medicine, ocean, groundwater and other aspects of evaluation and analysis, for example, evaluation of catalytic pyrolysis of cassava rhizome, evaluation of the partial organ tolerance of normal tissues to radiation and evaluation of ground water quality have all been analyzed by principal component analysis [15-18].

At present, the evaluation of the gas-fired combi-boilers is only based on China national product standards "GB 250342010 " to determine whether it is qualified, and cannot comprehensively and quantitatively determine the performance of the combi-boilers or give the ranking of combi-boilers. In the previous studies, factor analysis and cluster analysis are rarely used to evaluate the operation performance of boilers. Therefore, combined with the above analysis, the performance of gas-fired heating and hot water combi-boilers can be evaluated and analyzed by factor analysis and cluster analysis, which can be provided as a method for quantitative evaluation of boilers.

The main performance of the combi-boilers includes economic performance and safety performance, among which the economic performance is mainly reflected in the level of useful efficiency, while the safety performance is mainly reflected in the concentration of dry combustion products. Compared with the combustion characteristics of gas-fired combi-boilers, seven indicators including useful efficiency at rated input in heating mode, exhaust temperature, concentration of $\mathrm{O}_{2}, \mathrm{CO}, \mathrm{CO}_{2}$ of the dry combustion products, useful efficiency at $50 \%$ of the nominal input in hot water mode and weighted value of the $\mathrm{NO}_{x}$ concentration have been selected for performance evaluation.

The purpose of this study presented here is to provide a quantitative evaluation method for the operation performance of the combi-boilers. For performing this aim, few combi-boilers have been tested, and the evaluation model are developed with factor analysis method. Then, the key factors affecting the evaluation of operation performance are determined with cluster analysis method. 


\section{Experiment and method}

\subsection{Sample selection}

Taking 20 gas-fired heating and hot water combi-boilers as an example, the operation performance is evaluated by principal component analysis.

The selected samples have a rated heat input distribution of 20-40 kW and closed heating system structure. The burners are atmospheric burners, and the structure and head of burner are grate structure and harmonica structure, which made of stainless steel. The heat exchanger is made of finned copper coil. The fan type includes fixed frequency and variable frequency fan. The heat exchange methods include plate heat exchanger heat transfer and casing heat transfer. The gas type used during the test is natural gas (12 T).

\subsection{Test rig}

Figures 1 and 2 are the system schematic and interior structure of the gas-fired heating and hot water combi-boiler,

\subsection{Test method}

(1) Useful efficiency at the rated heat input in heating mode

The boiler is installed on the insulated test rig (see Fig. 2), and the measurement of the efficiency may begin once the boiler, with the control thermostat put out of action, is at thermal equilibrium and the return and flow temperatures are constant. The hot water is passed into a vessel placed on scales (suitably tared before the test) and at the same time measurement of the gas rate (reading the meter) is started. Reading of the water return and flow temperatures are taken periodically so as to obtain a sufficiency accurate average.

Mass $m_{1}$ of water is collected during the $10 \mathrm{~min}$ of the test. A further $10 \mathrm{~min}$ wait is required in order to evaluate the evaporation corresponding to the test period. Mass $m_{2}$ is obtained. $m_{1}-m_{2}=m_{3}$, the quantity of which note has to be taken in order to increase $\mathrm{mt}$ by the value corresponding to the evaporation, whence the corrected water mass $m=m_{1}+m_{3}$. The quantity of heat transferred by the boiler to the water collected in the vessel is proportional to the corrected mass $m$ and to the difference between temperature $T_{1}$ at the cold water inlet and $T_{2}$ at the boiler outlet. The useful thermal efficiency is determined by means of the following formula:
Fig. 1 Schematic diagram of test system

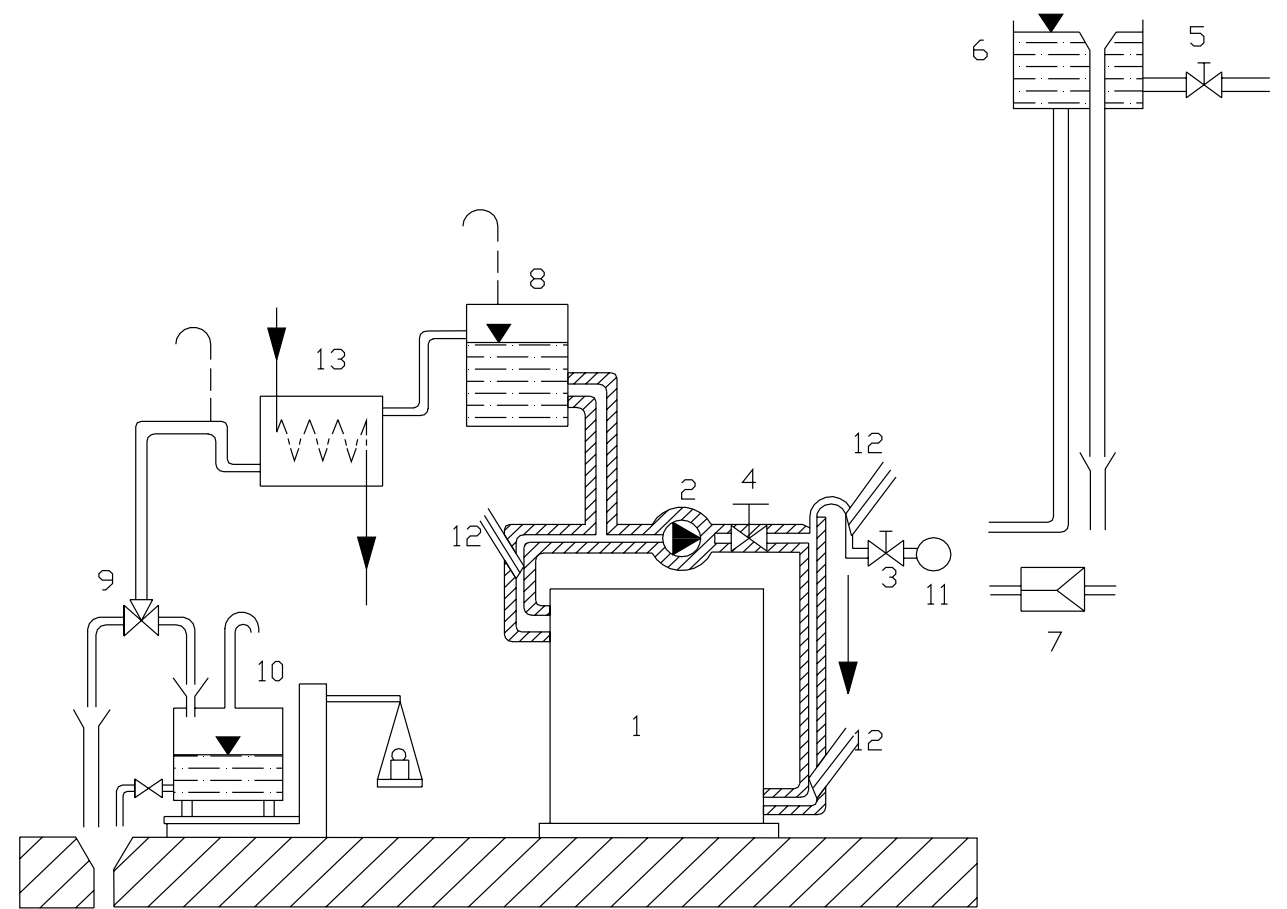

SN Applied Sciences a SPRINGER NATURE journal 
Fig. 2 Test rig

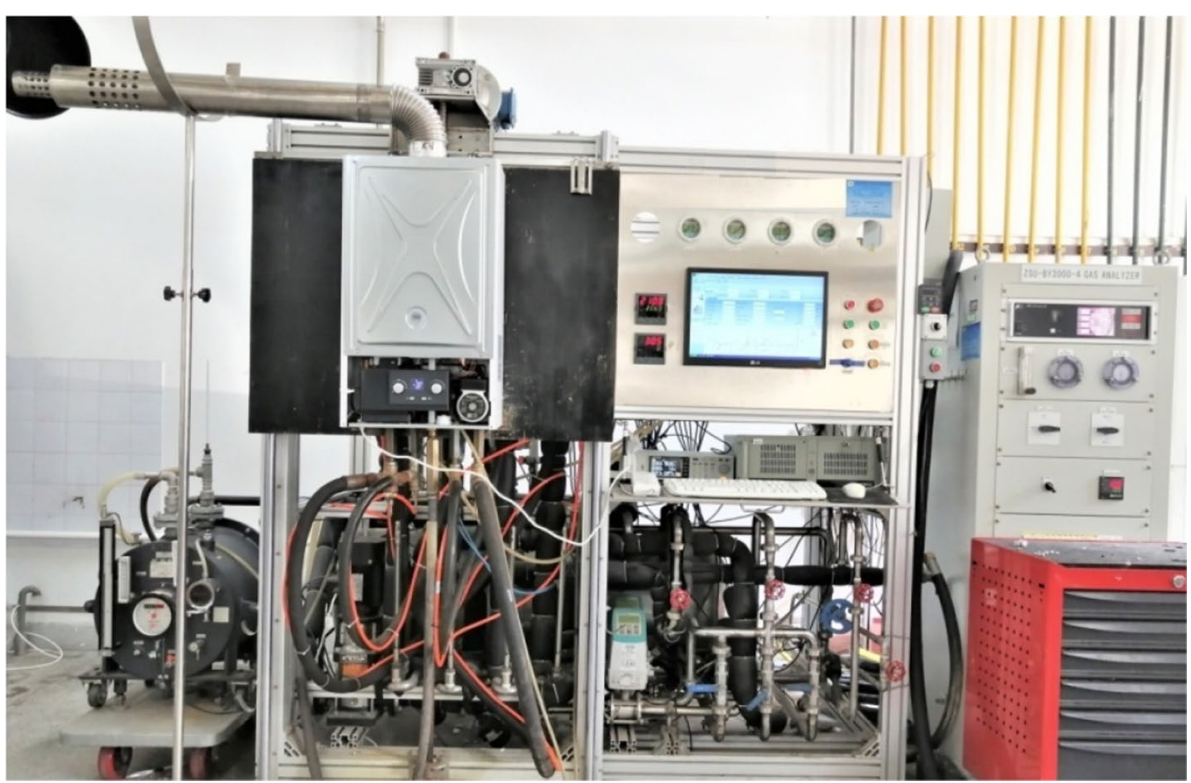

$\eta_{u}=\frac{4.186 \times m \times\left(T_{2}-T_{1}\right)+D_{\mathrm{p}}}{10^{3} \times V_{\mathrm{r}(10)} \times H_{i}} \times 100$

where $\eta_{u}$ is the useful efficiency in percent, $m$ is the corrected quantity of water expressed in $\mathrm{kg}, 4.186$ is the specific heat of water in $\mathrm{kJ} /\left(\mathrm{kg}{ }^{\circ} \mathrm{C}\right), T_{1}$ is the temperature at the cold water inlet at $60 \pm 1 \mathrm{in}{ }^{\circ} \mathrm{C}, T_{2}$ is the temperature at the boiler outlet at $80 \pm 1$ in ${ }^{\circ} \mathrm{C}, V_{\mathrm{r}(10)}$ is the fuel gas flow consumption in $\mathrm{m}^{3}$ measured during the test corrected to $15^{\circ} \mathrm{C}, 101,325 \mathrm{mbar}, H_{i}$ is the net calorific value of the gas used, in $\mathrm{MJ} / \mathrm{m}^{3}$ at $15^{\circ} \mathrm{C}, 101,325$ mbar, dry gas, $D_{\mathrm{p}}$ is the heat loss from the test rig corresponding to the mean water flow temperature, expressed in $\mathrm{kJ}$, taking into account the heat loss from the circulation pump, by calculating the heat loss of the experimental device, the heat loss is generally $0.5 \mathrm{~kW}$.

\section{(2) Combustion products sampling}

The sample of the combustion products is taken in the plane perpendicular to the direction of flow of the combustion products, and a distance from the extreme end of the combustion products duct is equal to the internal diameter of the combustion products evacuation duct, the distance is generally $60 \mathrm{~mm}$. The other end of the sampling probe is connected to the ZSU-BY3000-4 flue gas analyzer.

(3) Useful efficiency at $50 \%$ of the nominal heat input in hot water mode

The inlet water temperature is kept constant at $20 \pm 1{ }^{\circ} \mathrm{C}$, the outlet temperature of hot water is adjusted to be
$20 \mathrm{~K}$ higher than the inlet water temperature, and the useful efficiency test is started when the thermal equilibrium state is reached and the outlet temperature remains constant.

$\eta_{s}=\frac{4.186 \times m^{\prime} \times\left(T_{2}^{\prime}-T_{1}^{\prime}\right)}{10^{3} \times V_{\mathrm{r}(10)} \times H_{i}} \times 100$

where $\eta_{s}$ is the useful efficiency in percent, 4.186 is the specific heat of water in $\mathrm{kJ} /\left(\mathrm{kg} \cdot{ }^{\circ} \mathrm{C}\right), \mathrm{m}^{\prime}$ is the quantity of domestic hot water produced expressed in $\mathrm{kg}, T_{1}^{\prime}$ is the inlet domestic hot water temperature at $20 \pm 1 \mathrm{in}{ }^{\circ} \mathrm{C}, T_{2}^{\prime}$ is the outlet domestic hot water temperature at $40 \pm 1$ in ${ }^{\circ} \mathrm{C}$.

\section{(4) Weighted value of $\mathrm{NO}_{x}$ concentration}

The test method of weighted value of $\mathrm{NO}_{x}$ concentration is in accordance with the China national standard GB 25034-2010 "Gas-fired heating and hot water combi-boilers".

The return water temperature $T_{r}$ is calculated as a function of the particular heat input using the following formula:

$T_{r}=0.4 Q+20$

where $T_{r}$ is the return water temperature expressed in ${ }^{\circ} \mathrm{C}$, $Q$ is the partial heat input expressed in percent of nominal heat input.

The $\mathrm{NO}_{x}$ value is specified below: 


$$
\begin{aligned}
\left(\mathrm{NO}_{x}\right)_{0}= & \left(\mathrm{NO}_{x}\right)_{m}+\frac{0.02\left(\mathrm{NO}_{x}\right)_{m}-0.34}{1-0.02\left(h_{m}-10\right)} \\
& \times\left(h_{m}-10\right)+0.85 \times\left(20-T_{m}\right)
\end{aligned}
$$

where $\left(\mathrm{NO}_{x}\right)_{m}$ is the concentration of $\mathrm{NO}_{x}$ in the dry flue gas at $h_{m}$ and $T_{m}$ in $\mathrm{mg} / \mathrm{kWh}, h_{m}$ is humidity of the air in $\mathrm{g} / \mathrm{kg} ; T_{m}$ is wt bulb temperature of air in ${ }^{\circ} \mathrm{C} ;\left(\mathrm{NO}_{x}\right)_{0}$ is the corrected value of $\mathrm{NO}_{x}$ expressed in $\mathrm{mg} / \mathrm{kWh}$.

The weighted value of the $\mathrm{NO}_{x}$ concentration is calculated as follows:

$$
\left(\mathrm{NO}_{x}\right)_{\text {pond }}=0.15\left(\mathrm{NO}_{x}\right)_{m(70)}+0.25\left(\mathrm{NO}_{x}\right)_{m(60)}+0.60\left(\mathrm{NO}_{x}\right)_{m(40)}
$$

where $\left(\mathrm{NO}_{x}\right)_{\text {pond }}$ is the weighted value of the $\mathrm{NO}_{x}$ concentration in milligram per kilowatt-hour $(\mathrm{mg} / \mathrm{kWh}),\left(\mathrm{NO}_{x}\right)_{m(70)}$ $\left(\mathrm{NO}_{x}\right)_{m(60)},\left(\mathrm{NO}_{x}\right)_{m(40)}$ are the measured value at the partial heat input.

\section{Results and analysis}

\subsection{Test results}

The useful efficiency at rated input in heating mode, the exhaust temperature, the concentration of $\mathrm{O}_{2}, \mathrm{CO}, \mathrm{CO}_{2}$ of the dry combustion products, the useful efficiency at $50 \%$ of the nominal input in hot water mode and the weighted
Table 1 Test results of 20 samples

\begin{tabular}{lllrllll}
\hline Sample & $\begin{array}{l}\text { Efficiency at } \\
\text { rated input } \\
(\%)\end{array}$ & $\begin{array}{l}\text { Exhaust } \\
\text { temperature } \\
\left({ }^{\circ} \mathrm{C}\right)\end{array}$ & $\mathrm{O}_{2}(\%)$ & $\mathrm{CO}$ & $\mathrm{CO}_{2}(\%)$ & $\begin{array}{l}\text { Efficiency at } 50 \% \\
\text { nominal input }(\%)\end{array}$ & $\begin{array}{l}\left(\mathrm{NO}_{x}\right)_{\text {pond }} \\
(\mathrm{mg} \\
(\mathrm{kWh})\end{array}$ \\
\hline $1 \#$ & 91.65 & 126 & 10.8 & $37 \times 10^{-6}$ & 5.9 & 88.25 & 133 \\
$2 \#$ & 89.40 & 128 & 11.7 & $10 \times 10^{-6}$ & 5.2 & 88.71 & 132 \\
$3 \#$ & 93.43 & 123 & 5.7 & $122 \times 10^{-6}$ & 8.8 & 92.98 & 142 \\
$4 \#$ & 89.64 & 147 & 11.8 & $28 \times 10^{-6}$ & 5.0 & 88.29 & 125 \\
$5 \#$ & 93.96 & 122 & 6.8 & $128 \times 10^{-6}$ & 7.8 & 92.20 & 147 \\
$6 \#$ & 92.41 & 139 & 9.7 & $58 \times 10^{-6}$ & 6.4 & 91.01 & 153 \\
$7 \#$ & 92.18 & 124 & 9.8 & $12 \times 10^{-6}$ & 6.2 & 91.62 & 130 \\
$8 \#$ & 90.70 & 129 & 11.8 & $18 \times 10^{-6}$ & 5.1 & 87.38 & 175 \\
$9 \#$ & 92.02 & 115 & 10.7 & $38 \times 10^{-6}$ & 6.1 & 89.96 & 136 \\
$10 \#$ & 91.48 & 135 & 8.8 & $55 \times 10^{-6}$ & 7.3 & 89.36 & 127 \\
$11 \#$ & 91.76 & 124 & 9.5 & $53 \times 10^{-6}$ & 6.9 & 91.94 & 131 \\
$12 \#$ & 91.96 & 132 & 10.7 & $13 \times 10^{-6}$ & 5.9 & 91.33 & 130 \\
$13 \#$ & 92.24 & 122 & 10.9 & $43 \times 10^{-6}$ & 5.9 & 90.94 & 132 \\
$14 \#$ & 93.25 & 120 & 8.9 & $21 \times 10^{-6}$ & 7.1 & 90.10 & 148 \\
$15 \#$ & 93.04 & 124 & 8.2 & $93 \times 10^{-6}$ & 7.3 & 89.33 & 139 \\
$16 \#$ & 91.72 & 143 & 10.1 & $69 \times 10^{-6}$ & 6.0 & 88.73 & 136 \\
$17 \#$ & 90.00 & 142 & 11.7 & $20 \times 10^{-6}$ & 5.3 & 88.63 & 136 \\
$18 \#$ & 92.44 & 121 & 10.4 & $37 \times 10^{-6}$ & 5.9 & 90.77 & 87.71 \\
$19 \#$ & 90.64 & 137 & 10.5 & $54 \times 10^{-6}$ & 5.9 & 88.09 & \\
$20 \#$ & 91.34 & 120 & 11.9 & $12 \times 10^{-6}$ & 5.0 & & \\
\hline & & & & & & & 172 \\
\hline
\end{tabular}

Table 2 Correlation coefficient matrix

\begin{tabular}{lccccccc}
\hline Index & $\begin{array}{l}\text { Efficiency at } \\
\text { rated input }\end{array}$ & $\begin{array}{l}\text { Exhaust tem- } \\
\text { perature }\end{array}$ & $\mathrm{O}_{2}$ & $\mathrm{CO}$ & $\mathrm{CO}_{2}$ & $\begin{array}{l}\text { Efficiency at 50\% } \\
\text { nominal input }\end{array}$ & $\begin{array}{c}\left(\mathrm{NO}_{x}\right)_{\text {pond }} \\
\text { Efficiency at rated input }\end{array}$ \\
Exhaust temperature & 1.000 & 0.564 & 0.796 & -0.628 & 0.785 & 0.709 & -0.014 \\
$\mathrm{O}_{2}$ & 0.564 & 1.000 & 0.286 & -0.090 & 0.323 & 0.399 & -0.020 \\
$\mathrm{CO}$ & 0.796 & 0.286 & 1.000 & -0.853 & 0.983 & 0.684 & -0.010 \\
$\mathrm{CO}_{2}$ & -0.628 & -0.090 & -0.853 & 1.000 & -0.806 & -0.463 & 0.104 \\
Efficiency at 50\% nominal input & 0.785 & 0.323 & 0.983 & -0.806 & 1.000 & 0.691 & 0.021 \\
$\left(\mathrm{NO}_{x}\right)_{\text {pond }}$ & 0.709 & 0.399 & 0.684 & -0.463 & 0.691 & 1.000 & 0.357 \\
\hline
\end{tabular}


value of the $\mathrm{NO}_{x}$ concentration of the 20 gas-fired heating and hot water combi-boilers have been tested respectively. 20 samples of different production enterprises and different heat input are selected randomly. The test results of 20 samples are shown in Table 1.

\subsection{Correlation analysis}

The test indicators have been standardized with SPSS software. The correlation between the evaluation indicators is analyzed, and the correlation coefficient matrix between the evaluation indexes is expressed in tabular form as shown in Table 2.

According to the criterion of correlation, the closer the absolute value of the correlation coefficient is to 1 , the stronger the correlation. It can be seen from Table 2 that there is a significant correlation between the efficiency and combustion exhaust gas, and the correlations between $\mathrm{O}_{2}$ and $\mathrm{CO}_{2}$ is more significant. It can be known that there is a certain correlation between the seven indexes, and some of the correlations are high. Therefore, it is reasonable to extract the principal component common factor for principal component analysis from the seven independent indicators.

According to the KMO metric given by Kaiser, the factor analysis can be performed if the KMO value is above 0.5 , and the output of this analysis is 0.748 , so the selected variable is suitable for factor analysis. The Bartlett's test of sphericity has completed the independence test between the variables by converting to the $\chi^{2}$ test. According to the analysis output, Bartlett's sphericity test statistic is 121.665 , and the Sig. is 0.00 , which is significantly less than the significance level of 0.005 , so the null hypothesis of the Bartlett's sphericity test is rejected, indicating that the correlation coefficient matrix is significantly different from the identity matrix, and the selected variable can be performed with factor analysis.

\subsection{Principal components analysis}

\subsubsection{Principal components extraction}

Taking Table 2 as a correlation coefficient matrix, with the data analysis software SPSS, the eigenvalues and eigenvectors can be obtained by solving the coefficient matrix. The number of eigenvalues is the number of components. The variance contribution rate of the k principal component is the ratio of the eigenvalue of the $k$ principal component and the sum of all eigenvalues. The cumulative variance contribution rate of the $k$ principal components is the sum of the first $k$ variance contribution rate. The data processing results are shown in Table 3

Principal component analysis is the method that using few variables to reflect the information of the original variables as much as possible. It is generally believed that most important information can be retained while the cumulative variance contribution rate is greater than $85 \%$. It can be seen from Table 3 that the cumulative contribution rate of the first three main components is $91.118 \%$

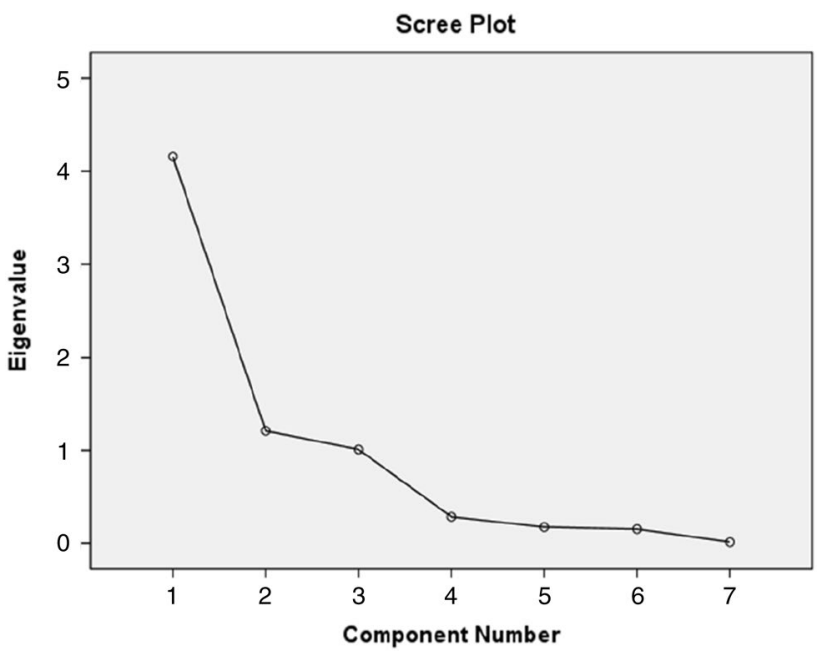

Fig. 3 Scree plot of component factor

Table 3 Total variance explained

\begin{tabular}{|c|c|c|c|c|c|c|c|c|c|}
\hline \multirow[t]{2}{*}{ Component } & \multicolumn{3}{|c|}{ Initial eigenvalues } & \multicolumn{3}{|c|}{ Extraction sums of squared loadings } & \multicolumn{3}{|c|}{ Rotation sums of squared loadings } \\
\hline & Total & $\%$ of Variance & Cumulative \% & Total & $\%$ of Variance & Cumulative \% & Total & $\%$ of variance & Cumulative \% \\
\hline 1 & 4.160 & 59.425 & 59.425 & 4.160 & 59.425 & 59.425 & 1.109 & 15.847 & 15.847 \\
\hline 2 & 1.210 & 17.279 & 76.704 & 1.210 & 17.279 & 76.704 & 1.089 & 15.555 & 31.401 \\
\hline 3 & 1.009 & 14.414 & 91.118 & 1.009 & 14.414 & 91.118 & 1.054 & 15.054 & 46.455 \\
\hline 4 & 0.284 & 4.059 & 95.178 & 0.284 & 4.059 & 95.178 & 1.012 & 14.456 & 60.912 \\
\hline 5 & 0.173 & 2.477 & 97.654 & 0.173 & 2.477 & 97.654 & 0.947 & 13.533 & 74.445 \\
\hline 6 & 0.152 & 2.173 & 99.827 & 0.152 & 2.173 & 99.827 & 0.916 & 13.087 & 87.532 \\
\hline 7 & 0.012 & 0.173 & 100.000 & 0.012 & 0.173 & 100.000 & 0.873 & 12.468 & 100.000 \\
\hline
\end{tabular}


and greater than $85 \%$. Figure 3 is the gravel map of the eigenvalue. The abscissa is the number of components, and the ordinate is the eigenvalue of the component. The figure shows that the amplitude of variation of eigenvalues varies greatly in the first 3-4 component and tends to be stable after fourth component, which indicates that it is reasonable to extract three indicators as the main components, which can summarize most of the information.

\subsubsection{Principal components loading}

It can be seen from Tables 3 and 4 that the indicators of useful efficiency at rated input in heating mode, concentration of $\mathrm{O}_{2}$ and $\mathrm{CO}_{2}$ have a greater loading on the first principal component, and the corresponding loadings are $0.902,0.958$ and 0.952 , respectively, and the contribution of the first principal component to the comprehensive evaluation index is reached $59.425 \%$. The indicator of weighted value of $\mathrm{NO}_{x}$ concentration has the largest loading on the second principal component, the corresponding loading is 0.885 and the contribution is $17.279 \%$. The indicator of concentration of $\mathrm{CO}$ has the largest loading on the third principal component, the corresponding loading is 0.806 and the contribution is $14.414 \%$. Combined with the cumulative and the loading corresponding to the principal component, it can be seen that useful efficiency at rated input in heating mode and concentration of $\mathrm{O}_{2}$ and $\mathrm{CO}_{2}$ has a greater impact on performance evaluation.

\subsection{Factor analysis}

\subsubsection{Factor loading}

Seven indictors of 20 gas-fired heating and hot water combi-boilers are analyzed with factor analysis, three principal components have been extracted and the cumulative contribution rate of the first three main components is $91.118 \%$, so it can be known that the three principal components can reflect $91.118 \%$ information of the seven indictors, which is highly representative. In order to obtain a more independence between the seven indicators, the factors have been rotated with the maximum variance method. With the rotation, the factor loading is concentrated to both ends, which can better explain the common factors. The results are shown in Table 5.

\subsubsection{Factor scores and ranking}

Taking the contribution rate of each component as the weight, the function of comprehensive performance evaluation score is constructed:

$$
F=0.652 F_{1}+0.190 F_{2}+0.158 F_{3}(6)
$$

The performance scores of each combi-boiler can be calculated with Eq. (6), and the comprehensive ranking of the operation performance of 20 gas-fired combi-boilers can be obtained with the values sorted from large to small in descending order. The rankings of the 20 samples are shown in Table 6 . It can be seen that the comprehensive

Table 4 Component matrix

\begin{tabular}{lrrrrrrr}
\hline Index & \multicolumn{7}{l}{ Component } \\
\cline { 2 - 8 } & 1 & 2 & 3 & \multicolumn{1}{l}{4} & 5 & 6 & 7 \\
\hline Efficiency at rated input & 0.902 & 0.026 & 0.237 & 0.081 & -0.328 & 0.124 & -0.006 \\
Exhaust temperature & 0.469 & 0.268 & 0.806 & -0.211 & 0.091 & -0.075 & 0.004 \\
$\mathrm{O}_{2}$ & 0.958 & -0.158 & -0.162 & -0.036 & 0.107 & 0.107 & 0.084 \\
$\mathrm{CO}$ & -0.809 & 0.361 & 0.310 & 0.217 & 0.088 & 0.252 & 0.011 \\
$\mathrm{CO}_{2}$ & 0.952 & -0.110 & -0.133 & -0.047 & 0.173 & 0.164 & -0.069 \\
Efficiency at 50\% nominal input $_{\left(\mathrm{NO}_{x}\right)_{\text {pond }}}$ & 0.802 & 0.431 & -0.043 & 0.367 & 0.075 & -0.166 & -0.003 \\
\hline
\end{tabular}

Table 5 Rotated factor loading matrix

\begin{tabular}{llrrrrrr}
\hline Index & \multicolumn{1}{l}{ Component } \\
\cline { 2 - 8 } & 1 & 2 & 3 & 4 & 5 & 6 & 7 \\
\hline Efficiency at rated input & -0.340 & 0.250 & 0.029 & 0.318 & 0.747 & 0.278 & 0.291 \\
Exhaust temperature & 0.963 & 0.010 & -0.019 & -0.146 & -0.194 & -0.085 & -0.081 \\
$\mathrm{O}_{2}$ & 0.094 & -0.432 & -0.020 & -0.297 & -0.334 & -0.503 & -0.594 \\
$\mathrm{CO}$ & 0.033 & 0.824 & 0.082 & 0.161 & 0.254 & 0.330 & 0.338 \\
$\mathrm{CO}_{2}$ & -0.134 & 0.369 & -0.009 & 0.293 & 0.307 & 0.642 & 0.504 \\
Efficiency at 50\% nominal input & -0.197 & 0.150 & -0.262 & 0.818 & 0.285 & 0.243 & 0.246 \\
$\left(\mathrm{NO}_{x}\right)_{\text {pond }}$ & -0.020 & 0.049 & 0.988 & -0.142 & 0.013 & 0.003 & 0.006 \\
\hline
\end{tabular}


Table 6 Factor scores and comprehensive scores

\begin{tabular}{llrrll}
\hline Sample & \multicolumn{1}{l}{$\mathrm{F}_{1}$} & \multicolumn{1}{l}{$\mathrm{F}_{2}$} & \multicolumn{1}{l}{$\mathrm{F}_{3}$} & Score & Ranking \\
\hline $1 \#$ & -0.823 & 0.357 & 0.217 & -0.434 & 13 \\
$2 \#$ & -2.455 & 0.828 & -0.016 & -1.446 & 17 \\
$3 \#$ & 4.738 & -0.436 & -0.669 & 2.901 & 1 \\
$4 \#$ & -2.855 & 0.470 & -1.974 & -2.084 & 20 \\
$5 \#$ & 4.057 & -0.729 & -0.135 & 2.486 & 2 \\
$6 \#$ & 0.512 & -0.788 & -0.670 & 0.078 & 10 \\
7\# & 0.360 & 1.512 & 0.412 & 0.587 & 6 \\
$8 \#$ & -2.402 & -1.959 & 1.329 & -1.728 & 18 \\
$9 \#$ & 0.124 & 0.862 & 1.265 & 0.445 & 8 \\
$10 \#$ & 0.501 & -1.731 & -0.375 & -0.061 & 12 \\
$11 \#$ & 1.167 & 1.265 & -0.244 & 0.963 & 5 \\
$12 \#$ & -0.374 & 1.263 & -0.192 & -0.034 & 11 \\
$13 \#$ & 0.179 & 1.235 & 0.490 & 0.429 & 9 \\
$14 \#$ & 1.251 & 0.916 & 0.786 & 1.114 & 3 \\
$15 \#$ & 1.968 & -1.037 & 0.123 & 1.105 & 4 \\
$16 \#$ & -0.523 & -0.696 & -1.497 & -0.710 & 14 \\
$17 \#$ & -2.464 & 0.113 & -1.139 & -1.765 & 19 \\
$18 \#$ & 0.295 & 0.903 & 0.795 & 0.489 & 7 \\
$19 \#$ & -1.347 & -1.059 & -0.735 & -1.195 & 16 \\
$20 \#$ & -1.909 & -1.292 & 2.229 & -1.138 & 15 \\
\hline
\end{tabular}

Table 7 Correlation analysis

\begin{tabular}{lrlrl}
\hline Index & \multicolumn{1}{l}{$\mathrm{F}_{1}$} & $\mathrm{~F}_{2}$ & \multicolumn{1}{l}{$\mathrm{F}_{3}$} & $\mathrm{~F}$ \\
\hline $\mathrm{F}_{1}$ & 1.000 & -0.001 & 0.001 & 0.981 \\
$\mathrm{~F}_{2}$ & -0.001 & 1.000 & -0.001 & 0.153 \\
$\mathrm{~F}_{3}$ & 0.001 & -0.001 & 1.000 & 0.118 \\
$\mathrm{~F}$ & 0.981 & 0.153 & 0.118 & 1.000 \\
\hline
\end{tabular}

evaluation index value of sample 3 is 2.901 , which is the highest of the 20 samples, so the comprehensive ranking is first, and the index value of sample 4 is -2.084 , which is the lowest of the 20 samples, so the ranking is 20th.

\subsubsection{Correlation analysis of scores}

The correlation analysis between the index comprehensive score and factor score is shown in Table 7. The comprehensive score and factor score 1 are significantly positively correlated $(P<0.01)$, and the correlation coefficient is 0.981 , indicating that the comprehensive score and factor score 1 have a good correlation; while the correlation between the three factor scores are all 0 , indicating that the performance evaluation information of combi-boilers represented by the three principal components does not overlap, which is consistent with the requirements for factor analysis.

\subsection{Cluster analysis}

As the factor score 1 has a good correlation with the comprehensive score, the system cluster analysis is carried out for 20 gas-fired combi-boilers based on the factor score 1, and the analysis results are shown in Fig. 4. When the class distance is 5, 20 gas-fired combi-boilers are copolymerized into 3 classes (see Table 8). The first category is the samples with a comprehensive score range of 2.486-2.901, which can be regarded as "products with high operation performance"; the second category is the samples with a comprehensive score range of $-0.710-1.114$, which can be regarded as "products with general operation performance"; the third category is the samples with a comprehensive score range of -2.084 to -1.138 , which can be regarded as "products with low operation performance".

Combined with Tables 8 and 9, it can be seen that the combi-boilers with higher operation performance have the higher thermal efficiency at rated input in heating mode and thermal efficiency at $50 \%$ of the nominal input in hot water mode and concentration of $\mathrm{CO}_{2}$ of dry combustion products, and lower concentration of $\mathrm{O}_{2}$ of dry combustion products, while the exhaust gas temperature, concentration of $\mathrm{CO}$ of dry combustion products and weighted value of $\mathrm{NO}_{x}$ concentration of the three types of products are not significantly different. Therefore, it is known that under the premise of the qualified gas-fired combi-boilers, the thermal efficiency at rated input in heating mode and thermal efficiency at $50 \%$ of the nominal input in hot water mode and concentration of $\mathrm{O}_{2}$ and $\mathrm{CO}_{2}$ of dry combustion products have the greatest impact on the comprehensive operation performance evaluation of combi-boilers, which is in accordance with the indicators with higher loading in the first principal component.

\section{Discussions}

With factor analysis, the evaluation model is obtained and can be used to quantitatively determine the quality of boilers. With cluster analysis, the key factors influence evaluation model are determined. The results of factor analysis and cluster analysis show that thermal efficiency, concentration of $\mathrm{O}_{2}$ and $\mathrm{CO}_{2}$ are the most significant factors that influence the performance of combi-boilers.

Thermal efficiency is the proportion of heat effective heating circulating water to the heat released by gas combustion. In terms of economy, for the same heat required, the higher the thermal efficiency is, the less gas consumption is. In this way, a low gas cost and higher economy can be obtained. Therefore, the higher the thermal efficiency, the better the combi-boilers performance, and the combiboiler has a high ranking. 
Fig. 4 Cluster analysis dendrogram
Table 8 Results of operation performance evaluation with cluster analysis

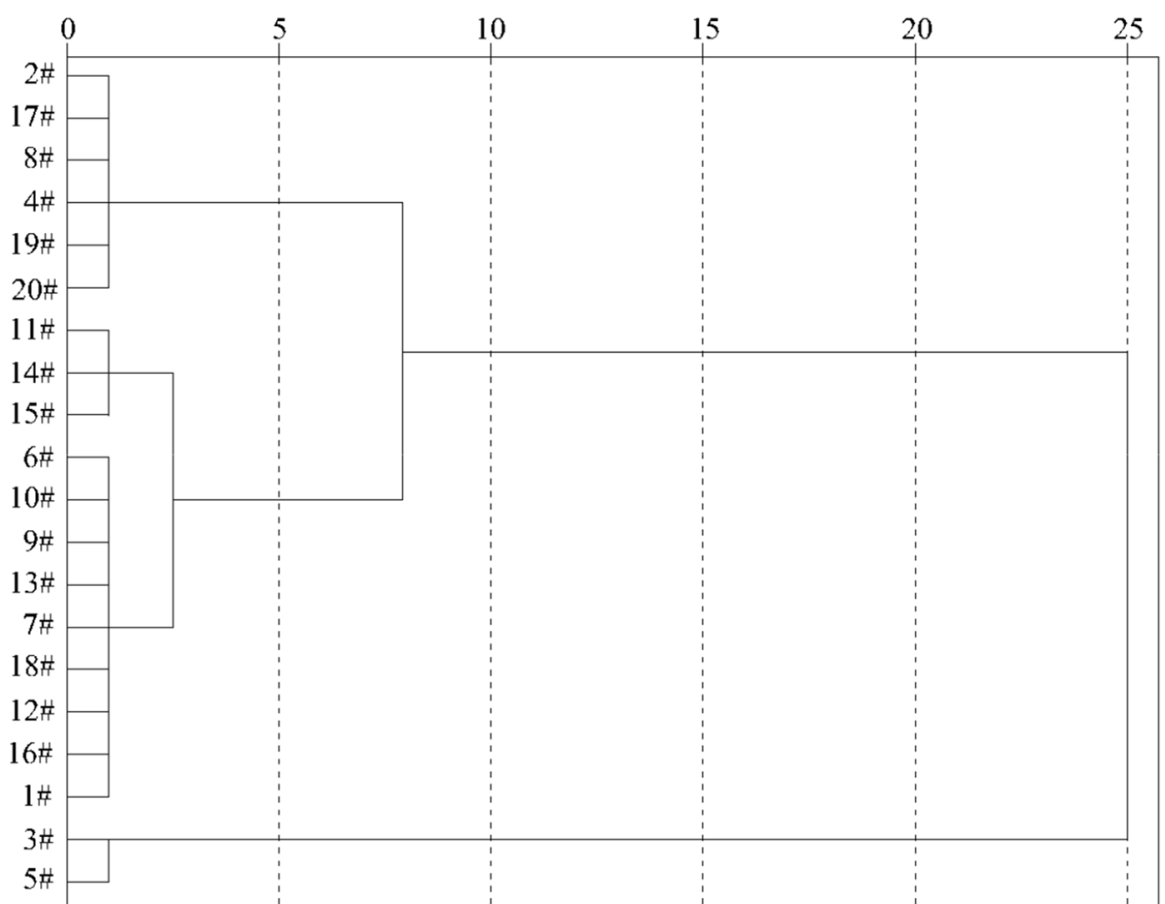

\begin{tabular}{llcc}
\hline Product category & $\begin{array}{l}\text { Comprehensive } \\
\text { score range }\end{array}$ & Average score & Sample number \\
\hline High operation performance & $2.486-2.901$ & 2.693 & $3 \#, 5 \#$ \\
General operation performance & $-0.710-1.114$ & 0.331 & $1 \#, 6 \#, 7 \#, 9 \#, 10 \#, 11 \#$, \\
& & & $12 \#, 13 \#, 14 \#, 15 \#, 16 \#$, \\
Low operation performance & $-2.084--1.138$ & -1.559 & $2 \#, 4 \#, 8 \#, 17 \#, 19 \#, 20 \#$ \\
\hline
\end{tabular}

Table 9 Value range of evaluation index in different combi-boilers

\begin{tabular}{llllllll}
\hline Product category & $x_{1}(\%)$ & $x_{2}\left({ }^{\circ} \mathrm{C}\right)$ & $x_{3}(\%)$ & $x_{4}$ & $x_{5}(\%)$ & $x_{6}(\%)$ & $x_{7}(\mathrm{mg}(\mathrm{kWh})$ \\
\hline High operation performance & $93.43-93.96$ & $123-122$ & $5.7-6.8$ & $122-128$ & $8.8-7.8$ & $92.98-92.2$ & $142-147$ \\
General operation performance & $91.48-93.25$ & $115-143$ & $8.2-10.9$ & $12-93$ & $5.9-7.3$ & $88.25-91.94$ & $127-162$ \\
Low operation performance & $89.40-91.34$ & $120-147$ & $10.5-11.9$ & $10-54$ & $5.0-5.9$ & $87.38-88.71$ & $125-175$ \\
\hline
\end{tabular}

$\mathrm{O}_{2}$ is the air that needed for gas combustion, so the higher the concentration of $\mathrm{O}_{2}$ in the dry flue gas, the less $\mathrm{O}_{2}$ concentration involved in gas combustion. With the same volume of gas, the higher the $\mathrm{O}_{2}$ concentration in the flue gas, the less $\mathrm{O}_{2}$ concentration involved in gas combustion, and the less the gas combusted. According to the chemical reaction equation of gas combustion, a large amount of $\mathrm{CO}$ will be generated while the gas is not completely burned. Similarly, the higher the content of $\mathrm{CO}_{2}$, the lower the co generated and the better the combustion effect. Therefore, the lower the concentration of $\mathrm{O}_{2}$ and the higher the concentration of $\mathrm{CO}_{2}$ in flue gas, the better the operation performance of combi-boilers.
Thermal efficiency is regarded as an important factor affecting boiler performance [2], and thermal efficiency is the base for the performance of the reheat boiler design [19]. The performance of circulating fluidized bed boiler has been evaluated and results showed that the improved efficiency can improved performance of the boiler [20]. $\mathrm{O}_{2}$ and $\mathrm{CO}_{2}$ are mainly reflected in excess air coefficient, the optimization of excess air level in combustion process is one of the improving performance methods, and also can increase the efficiency of boiler [21]. The optimization of excess air also can improve the environment performance in a $150 \mathrm{MW}$ boiler [22]. Therefore, compared with the work published previously, it can be seen thermal efficiency, 
concentration of $\mathrm{O}_{2}$ and $\mathrm{CO}_{2}$ are the most significant factors that influence the performance of combi-boilers.

\section{Conclusions}

In this study, performance of gas-fired heating and hot water combi-boilers has been evaluated by factor analysis method. In the analyses, the evaluation model for the combi-boilers using the thermal efficiency, concentration of $\mathrm{O}_{2}, \mathrm{CO}, \mathrm{CO}_{2}$ and weighted value of $\mathrm{NO}_{x}$ concentration has been determined. With the evaluation model,the performance of combi-boilers can be determined quantitatively, and the ranking of combi-boilers can be given. Also in this study, the combi-boilers can be copolymerized into 3 classes with cluster analysis method, and the key factors affecting the evaluation of operation performance are also determined. The purpose of this paper is to provide a quantitative evaluation method for the operation performance of the combi-boilers, so the data used in this paper is mainly the test results. In the future research, the feedback of users using the boiler for a long time can be increased, in this way, the operation performance evaluation model of the whole life cycle of the combi-boiler can be obtained.

Acknowledgements This research was funded by the Key Project in the Tianjin Science and Technology Pillar Program under Grant number 19YFZCCG00550.

\section{Compliance with ethical standards}

Conflict of interest On behalf of all authors, the corresponding author states that there is no conflict of interest.

\section{References}

1. Wang S, Zhang S, Wang W, Wang C, Meng S (2012) Research on performance evaluation model of coal-fired boiler. In: 2012 third international conference on intelligent control and information processing (ICICIP). IEEE

2. Patel DT, Modi KV (2016) Performance evaluation of industrial boiler by heat loss method. Int J Adv Res Innov Ideas Educ 2(3):2081-2088

3. Mohapatra JN, Patil S, Sah R, Krishna PC (2018) Failure analysis and magnetic evaluation of tertiary superheater tube used in gas-fired boiler. J Mater Eng Perform 27(2):580-589

4. Fabio S, Anna S (2018) Experimental investigation of emissions and flame stability for steel and metal fiber cylindrical premixed burners. Combust Sci Technol 191:1-19

5. Wu Y, Luo C, Wu W, Su Q (2018) Denitration of the gas-fired boiler flue gas based on chemical-looping combustion. Chem Eng J 361:41-49
6. Cao W, Liu F, You X (2018) Performance of casting aluminumsilicon alloy condensing heating exchanger for gas-fired boiler. Heat Mass Transf 54(7):1951-1960

7. Cugley J, Lu G, Hossain MM, Yan Y, Searle I (2019) Visualisation and measurement of flames in a gas-fired multi-burner boiler. J Phys Conf Ser 1065(20):202009

8. Meng F, Dillingham G (2018) Life cycle analysis of natural gasfired distributed combined heat and power versus centralized power plant. Energy Fuels 32(11):11731-11741

9. Liu J, Sun F (2019) Experimental study on operation regulation of a coupled high-low energy flue gas waste heat recovery system based on exhaust gas temperature control. Energies 12:706

10. Yu J, Yoo J, Jang J, Park JH, Kim S (2017) A novel plugged tube detection and identification approach for final super heater in thermal power plant using principal component analysis. Energy 126:404-418

11. Karytsas S, Choropanitis I (2017) Barriers against and actions towards renewable energy technologies diffusion: a principal component analysis for residential ground source heat pump (GSHP) systems. Renew Sustain Energy Rev 78:252-271

12. Wang $S$, Chen $Y$ (2004) Sensor validation and reconstruction for building central chilling systems based on principal component analysis. Energy Convers Manag 45(5):673-695

13. Li K, Hu C, Liu G, Xue W (2015) Building's electricity consumption prediction using optimized artificial neural networks and principal component analysis. Energy Build 108:106-113

14. Reddy TA, Claridge DE (1994) Using synthetic data to evaluate multiple regression and principal component analyses for statistical modeling of daily building energy consumption. Energy Build 21(1):35-44

15. Pattiya A, Titiloye JO, Bridgwater AV (2010) Evaluation of catalytic pyrolysis of cassava rhizome by principal component analysis. Fuel 89(1):244-253

16. Parinet B, Lhote A, Legube B (2004) Principal component analysis: an appropriate tool for water quality evaluation and management-application to a tropical lake system. Ecol Model 178(3-4):295-311

17. Dawson LA, Biersack M, Lockwood G, Eisbruch A, Lawrence TS, Haken RKT (2005) Use of principal component analysis to evaluate the partial organ tolerance of normal tissues to radiation. Int J Radiat Oncol Biol Phys 62(3):829-837

18. Chenini I, Khemiri S (2009) Evaluation of ground water quality using multiple linear regression and structural equation modeling. Int J Environ Sci Technol 6(3):509-519

19. Zhu H, Che D, Liu M (2019) Performance evaluation of a novel double-reheat boiler with triple-rear passes. Appl Therm Eng 159:113801

20. Lee JM, Kim JS, Kim JJ (2003) Evaluation of the 200 MWe Tonghae CFB boiler performance with cyclone modification. Energy 28(6):575-589

21. Hamideh M, Abbas A, Saeid HA (2016) Study on performance and methods to optimize thermal oil boiler efficiency in cement industry. Energy Equip Syst 4(1):53-64

22. Kuprianov VI, Vicharn T (2003) Optimization of excess air for the improvement of environmental performance of a $150 \mathrm{MW}$ boiler fired with Thai lignite. Appl Energy 74(3):445-453

Publisher's Note Springer Nature remains neutral with regard to jurisdictional claims in published maps and institutional affiliations. 